\title{
Fungal Diversity of Vermicompost Produced from the Major Municipal Solid Waste - Tendu (Diospyros melanoxylon) Leaf Litter Generated from Solapur City
}

\author{
Kothur Raghavender Rao ${ }^{1}$, Laxmi Mushan ${ }^{2}$ \\ ${ }^{1}$ Department of Zoology Walchand College of Arts and Science, Solapur, Maharastra, India \\ ${ }^{2}$ PG Department of Zoology D.B.F.Dayanand college of Arts and Science, Solapur, Maharashtra, India
}

\begin{abstract}
Waste management is considered as a major recycling process in the society, thereby helping the biodegradable products into useful nutritive products that can be utilized later in the agriculture. Earthworms excrete vermicast in the form of humus containing macro, micro nutrients, useful soil microbes, fungus, phosphate solubilising microorganisms, phytohormones etc. Earthworms have become an integral part of the agriculturists since they rejuvenate the soil and indirectly taking the societal and waste recycling process and thereby avoiding illegal land filling of the waste generated from various Indian cities. Different fungal representatives present in the soil benefits the plants in various means. The proper supply of the nutrients needed for the plant growth is associated with various fungi. The present research work is aimed to understand the fungal community especially from the vermicompost generated from tendu leaf litter waste from Solapur city, Maharastra through beedi industry.
\end{abstract}

Keywords: Tendu leaf litter waste, vermicompost, E.eugeniae, E.foetida, Fungal biodiversity

\section{Introduction}

In India solid waste disposal is done through land filling and the suitable location of the waste land is becoming increasingly difficult. In the developed countries waste disposal is becoming increasingly sophisticated in which complicated instruments are involved in recycling the waste. As a recent concept people are in a view that a waste generated in the form of solid is becoming a source of income. According to NEERI (Sunil Kumar, 2006) the municipal solid waste contains more than $30-40 \%$ of the organic fraction which can be recycled by proper scientific manner. Solapur is one of the major city from western Maharashtra and famous for textile and beedi industry. It has a population of 12 lakhs. The city is administered by Municipal Corporation. Solapur was once famous as a textile center and was also known as laborer's city. As per the survey, majority of labor communities are inclined towards the production of beedi as an alternate earning source. The beedi industry is one of the most thriving and popular industries. Approximately 70,000 people mostly women are engaged in the production of beedis. In Solapur, there are about 30 large beedi factories, which have around115 units of 20 small branches spread all over the city.

They are mostly concentrated in the eastern part of the city (Solapur Action plan, 2004). Madhya Pradesh is the biggest tendu leaf producing state. The average annual production of tendu leaves is around 25 lakhs standard bags, which is nearly $25 \%$ of total tendu leaf production of the country. The tendu, Diospyros melanoxylon Roxb. (Family: Ebonacae) is one of the most characteristic tree of the dry deciduous forest distributed throughout India. The tendu leaf is considered as most suitable wrapper of tobacco in beedi making, on account of the ease with which it can be rolled up. Its wide availability and texture favours its use in beedi making. Several beedi wrappers are used around the country, but the flavor, and workability of Diospyros melanoxylon is unmatchable. Another added character of tendu is its morphology. The thickness of the tendu leaf and its size makes Diospyros melanoxylon leaf the most ideal wrapper of tobacco. Tendu beedi making is a simple technique in which approximately $40-45 \%$ of leaf part is utilized for beedi preparation and remaining 50-60\% of the leaf is discarded as solid waste. In the absence of proper scientific method, the leaf waste is thrown on the streets and the improper disposal of leaf garbage leads to various environmental hazards. To resolve this problem an ecofriendly method of beedi leaf waste management was recommended to convert the waste biomass into biofertilisers using vermibiotechnology (Kadam et al, 2005; Mushan, 2010).

\section{Aim and Objectives}

The main aim of this study is to utilize the Tendu leaf waste by making its scientific use for its proper utilization and disposal.

Objectives

1) To convert the tendu leaf litter waste into useful vermicompost

2) To study the microbial populations and their role in plant growth.

\section{Literature Review}

Vermicomposting is an aerobic bioxidation process in which the waste organic matter is decomposed and fed to the earthworms which in turn produce the vermicasts rich in 


\section{International Journal of Science and Research (IJSR) \\ ISSN (Online): 2319-7064 \\ Index Copernicus Value (2013): 6.14 | Impact Factor (2015): 6.391}

nutrients and microbial population (Martin Cynthia and Rajesh Kumar, 2012).

Earthworm species Eudrilus eugeniae and Esenia foetida are exotic and acclimatized to the Indian climate, recycle the organic waste and convert to the biofertiliser (Daniel and Karmegam, (1999) Ismail, (1997). These earthworms reside in different levels of soil and can adapt to the various physico-chemical conditions of the agricultural land. Earthworm cast in which reside varied microorganisms and play a major role in maintaining the nitrogen levels in the soil (Furlong et al., 2002). Pressmud vermicompost worked by E.eugeniae has higher microbial population including bacteria, fungi and actinomycetes (Parthasarathi, 2007).

Few workers have studied fungal diversity from vermicompost. Abundance of fungal diversity is mainly associated with raw material and mesophilic conditions prevalent at the time of vermicomposting. Miller(1996) while studying fungal population observed that as many as 66 species found in compost including Aspergillus, Penicillium, Chladosporium etc. and considered them the most common composting materials because of their capacity to sustain higher temperature and degrade broad spectrum organic waste material. Many thousands of fungi species are found in soil as a temporary or permanent habitat. They include Mucor,Rhizopus, Penicillium, Aspergillus, Fusarium, Trichoderma,Chladosporium etc. When plant materials are added to the soil it was reported that fungal population is greatly stimulated (Prasad, 2011). Addition of cellulose to the soil will act as a nutritive material for the faster development of fungi. They will also decompose the cellulosic material found in various composts (Prasad, 2011).

Idowu et al (2006) studied the distribution of bacteria and fungi in the native earthworm of Nigeria (Mushan, 2010).They have isolated various fungal species from soil as well as gut sections and observed Aspergiluus, Candida and Fusarium species. They concluded that the microorganisms can make the soil fertile and later on it will benefit the biotic population. Dubey and Maheswari (1999) have studied that microbes like Pseudomonas Species, Aspergillus Species are known to mineralize phosphates. Alexi and Stephen (2000) have reviewed the microfungal community in soil litter and casts of Lumbicus terrestries. They stated that the majority of soil and litter inhabiting fungi survived passing through the gut of earthworm. The fungal communities of the cast consisted of mixture of soil and also litter inhabiting fungi. They noted that feeding and burrowing activity of this earthworm accelerates colonization of the litter by micro flora and also extend the range of occurrence of associated fungi into different soil layers.

Miller (1996) studied composting of municipal solid waste and its components and stated that fungi use many carbon sources chiefly lignocellulosic polymer and are chiefly responsible for compost maturation. A better understanding of fungal biodiversity in vermicompost may prove crucial in prediction of their best use. Therefore, study of fungal diversity is essential to optimize the quality standards of compost (Summebel, 1994).
Nirmalnath et al., (2006) stated that the fungi use many carbon sources mainly ligno-cellulosic polymers and can survive in extreme conditions and they are also involved in compost maturation. This may be true for the present investigation working with vermicompost produced from tendu leaf litter worked by Eisenia foetida in which total fungal population is increased and might be utilized for the maturation of vemicompost. It is also further stated that the fungi not only affects the soil fertility but suppress the plant diseases and promote mushroom growth (Stratesma and Samson, 1993). Eastman et al., (2001) have stated that earthworms stabilize organic residues and reduce pathogenic bacteria and other human pathogens and also greatly affect the fungal community. In the present investigation, the higher biodiversity of fungi may be due to favourable action of earthworms or to a more varied composition of organic raw material (tendu leaf litter) and persistent mesophilic conditions during the vermicomposting might have triggered more number of fungi. There is a greater species richness which is accompanied by greater evenness in the distribution of fungi observed in vermicompost. Cook and Lexton (1980) have isolated Mucor, Penicillum and Pseudomonas from soil and cultured them on the filter paper the earthworms were fed the fungus inoculated disk and observed the induction of fungi.

Nagavellamma et al., (2004) have recorded higher microbial populations in the partially decomposed dry organic waste material for vermicompost than the compost. They stated that the existing temperature and $\mathrm{pH}$ in partially decomposed raw material might have enhanced the number of microbes. They have also stated that in vermicompost, the fungi count was $8 \times 104 \mathrm{cfu} / \mathrm{g}$ and actinomycetes count was 1 x $104 \mathrm{cfu} / \mathrm{g}$ whereas in partially decomposed dry organic matter contains the $106 \mathrm{cfu} / \mathrm{g}$ the fungal count of 11 x 104 $\mathrm{cfu} / \mathrm{g}$ and actinomycetes 2 x $104 \mathrm{cfu} / \mathrm{g}$. They have further stated that much diversity was observed with reference to fungal isolates. There were some common genera like Aspergillus, Mucor,Chladosporium and Trichoderma from both the sample whereas the genera like Asperidia, Stabores were recorded in vermicompost. They further stated that the fungal diversity is much more in decomposed material than in vermicompost. It was interesting to know that from the samples the percentage of Aspergillus was more, the representatives of Trichoderma and Penicillium have also been noticed which indicate that they act as antibiotic against soil borne pathogens of the soil

\section{Materials and Methods}

\subsection{Overview of the experiment}

The experiments have been designed to understand the processing oftendu leaf litter waste generated from beedi industry. Earthworm species were used to produce vermicompost byproduct.

The protocol of the methodology was as follows:

\subsection{Collection of Waste Material and Processing}

Tendu leaf litter waste was collected from the local beedi collection centers at Maharashtra Industrial Development Corporation, Solapur. The tendu waste was sorted to 


\section{International Journal of Science and Research (IJSR) \\ ISSN (Online): 2319-7064 \\ Index Copernicus Value (2013): 6.14 | Impact Factor (2015): 6.391}

separate plastics, glass etc. This waste was pulverized by using a high speed mechanical pulveriser to a fine powdered state in the laboratory.

\subsection{Experimental Design}

Before vermicomposting, the Organic Raw Material (ORM) tendu (Diospyros melanoxylon) leaf litter waste needs to be partially decomposed for processing by earthworms. This was done by using a fungal decomposing mixture.

\section{a. Partial Decomposition of tendu (Diospyros melanoxylon) leaf litter waste \\ Five hundred kilograms of the pulverized tendu (Diospyros melanoxylon) leaf litter waste was collected and spread into a pit of size 3 metre long, 2 metre wide and 1meter deep.The pit was filled with five hundred kilograms tendu leaf powder and at every $30 \mathrm{~cm}$ a layer of soil and decomposing culture (consisting of Penicillium, Mucor and Trichoderma species) @ 1 kilogram per ton of tendu leaf litter powder was spread over it for partial decomposition. The decomposing pit was covered with a fine layer of soil so that anaerobic condition was created in the pit for decomposition. Temperature and humidity were \\ maintained at $32{ }^{\circ} \mathrm{C}$ and 35 - $45 \%$ respectively.}

b. Vermicomposting of partially decomposed tendu (Diospyros melanoxylon) leaf litter waste:

\section{Raised bed method using Eudrilus eugeniae and Eisenia foetida earthworm species.}

\section{Mass culturing of earthworms}

Thousand adult earthworms of each species of Eudrilus eugeniae and Eisenia foetida were obtained from Zonal Agricultural Research Station, Solapur and Institute of Natural Organic Agriculture, Pune respectively. The earthworms were multiplied on large scale by raised bed method (Parlekar and Pharande, 2005) under the shade of the size (6x3 mts) with natural day light

condition. Two raised vermicomposting beds of $2.0 \times 1.0 \times 0.5$ $\mathrm{m}$ size containing partially decomposed tendu leaf (ORM) (one hundred kilogram in each bed) as an earthworm feed were prepared in 6 feet $\mathrm{x} 3$ feet size vermicomposting shade under natural aerobic conditions at Karamba, in a private farm house. The beds were watered and 5000 adult earthworms of Eudrilus eugeniae and Eisenia foetida were released separately in each bed. The beds were protected from natural enemies. Bed temperature and humidity were maintained at $28 \pm 4{ }^{\circ} \mathrm{C}$ and $35-40 \%$ respectively by sprinkling water on the bed. litter was added in the bed for the next replications. The vermicompost thus obtained was analyzed for the microbes fungal popualton

\section{Microbial analysis}

Pour plate method has been used for the microbial analysis (Dubey and Maheshwari, 1999). One gram of the decomposed tendu leaf litter and tendu vermicompost each were suspended in ten milliliter of sterile solution and proper dilutions were made. Potato Dextrose Agar (PDA) and trace of steptocycline in the media for fungi, were used, in triplicates. Using standard platinum loop, $0.1 \mathrm{ml}$ of the inoculum was inoculated into respective media and incubated at $30{ }^{\circ} \mathrm{C}$ for 7 days for fungi. The viable colony count was done with the help of colony counter and the different colony forming units (cfu) developed on the media were estimated and expressed as cfu. The fungus was identified by Agharkhar research Institute, Pune based on morphological peculiarities.

Table 1: Variations in the total fungal count of vermicompost produced from tendu leaf liter processed by E.eugeniae and E.foetida compared with decomposed tendu.

Table 1: Variations in the total fungal count of vermicompost produced from tendu leaf liter processed by E.eugeniae and

\begin{tabular}{|c|c|c|c|c|c|}
\hline \multicolumn{6}{|c|}{ E.foetida compared with } \\
\hline Groups & $\begin{array}{c}\text { Total Fungal } \\
\text { Count } \\
\left(\begin{array}{c}100000 \mathrm{cfu} / \mathrm{gm}) \\
\text { days }\end{array}\right. \\
\end{array}$ & $\begin{array}{c}\text { Total Fungal Count } \\
\text { (100000cfu/gm)30 } \\
\text { days }\end{array}$ & $\begin{array}{c}\text { Fungal species } \\
\text { observed }\end{array}$ & $\begin{array}{c}\text { Total Phosphate } \\
\text { solubilising Fungal } \\
\text { Count } \\
(100000 \mathrm{cfu} / \mathrm{gm}) 30 \text { days }\end{array}$ & $\begin{array}{c}\text { Phosphate solubilising } \\
\text { Fungi observed }\end{array}$ \\
\hline $\begin{array}{c}\text { Control } \\
\text { decomposed tendu }\end{array}$ & $\mathbf{2 . 0 0} \pm 0.99$ & $8.00 \pm 0.81$ & $\begin{array}{c}\text { Aspergillus niger } \\
\text { Trichoderma spp. } \\
\text { Pencillium spp. } \\
\text { Rhizopus spp. }\end{array}$ & $10.20 \pm 0.19$ & $\begin{array}{l}\text { Aspergillus spp. } \\
\text { Trichoderma spp. } \\
\text { Rhizopus spp }\end{array}$ \\
\hline $\begin{array}{l}\text { Vermicompost } \\
\text { (E.eugeniae) }\end{array}$ & $\mathbf{6 . 0 0} \pm 0.08$ & $13.00 \pm 0.99 * *$ & $\begin{array}{l}\text { Pencillium spp. } \\
\text { Rhizopus spp. }\end{array}$ & $12.50 \pm 0.90$ & $\begin{array}{c}\text { Trichoderma spp. } \\
\text { Pencillium spp }\end{array}$ \\
\hline $\begin{array}{l}\text { Vermicompost } \\
\text { (E.foetida) }\end{array}$ & $13.00 \pm 0.12$ & $15.00 \pm 1.01^{* * *}$ & $\begin{array}{c}\text { Aspergillus niger } \\
\text { Trichoderma spp. } \\
\text { Pencillium spp. } \\
\text { Rhizopus spp. }\end{array}$ & $15.00 \pm 0.03$ & $\begin{array}{l}\text { Aspergillus spp. } \\
\text { Trichoderma spp. } \\
\text { Pencillium spp. } \\
\text { Aspergiilus niger }\end{array}$ \\
\hline
\end{tabular}

Values are significant at $* \mathrm{P}<0.05 * * \mathrm{P}<0.01 * * * \mathrm{P}<0.001$

Total Fungi (All the values are represented as $104 \mathrm{cfu} / \mathrm{g}$ ) The total microbial population was counted in decomposed tendu leaf litter and from vermicompost produced from tendu leaf (Diospyros melanoxylon) garbage processed by both the species of earthworms showed significant increase in the colony count as well in the density of the total fungi .The total fungi count in decomposed tendu leaf litter was $8.00+0.81$. In the vermicompost produced from tendu leaf litter worked by E.eugeniae showed increasing trend and was enhanced up to $13.00+0.99$. The percentage of increase was $62.50 \%$ when compared with decomposed tendu and was significant at $\mathrm{P}<0.01$ level. The total fungi from the vermicompost produced from tendu leaf litter processed by $E$. foetida showed an increasing trend in the total count up to $15.00+1.01$ and the percentage of increase was $87.5 \%$ and is significant at $\mathrm{P}<0.001$. The total count of fungi is found 


\section{International Journal of Science and Research (IJSR) \\ ISSN (Online): 2319-7064 \\ Index Copernicus Value (2013): 6.14 | Impact Factor (2015): 6.391}

to be more enhanced in the vermicompost worked by $E$. foetida when compared with E.eugeniae .Percentage of variation between the two vermicompost worked by

\section{Discussion}

Land pollution is the result of not only man's misuse but more due to solid waste disposal from the developed and developing countries. Generally solid wastes are dumped in oceans or open grounds. The industrial refuses contaminate the streams and lakes (Saxena, 2006).

Vermiculture is a profitable technology with immense potential of application in many fields. Different species of earthworms can be used for recycling the biodegradable organic waste to produce a rich bio-fertilizer useful for agriculture, horticulture etc. It has been noted that the earthworms can also be used for pharmaceutical products (Reynold and Reynold, 1972), weed

management (Edwards and Lofty, 1977) production of cheap animal protein (Guerro, 1983), poultry waste (Mba, 1996), decomposition and production of organic fertilizers from plant litter (Daniel and Karmegam, 1999; Kadam 2005; Katavkar et al., 2008) agro industrial waste (Kale, 2000), municipal solid waste (Booth et al., 2000). The vermicomposting is a process involved in bio oxidation and stabilization of organic raw material involving joint action of earthworms and microorganisms. Earthworms are the important drivers of the process, conditioning the substrate and altering the biological activity although microbes responsible for biochemical degradation of the organic matter (Aira et al., 2002;Suthar 2006).Mychorizal fungi makes phosphorus available to the plants easily. Certain microbes even detoxify pesticides too (Lynch, 1983 Subbarao, 2007).

The present investigation was carried out to study the variations in the microbial content of the decomposed tendu, vermicompost produced from tendu leaf litter worked by Eudrilus euginae and Eisenia foetida. It was observed that the fungi population increased in the vermicompost produced by Eudrilus euginae and Eisenia foetida from the tendu leaf litter.

The increase in the microbial population count from the vermicompost produced from both the species might have enhanced the biological activities of the cast. It is also stated that the microbial community in the vermicompost will promote the vermicomposting process and the metabolic potential would be dealt with the degree of organic matter degradation and stabilization. In the present investigation the total fungal count from decomposed tendu leaf litter and vermicompost produced from tendu leaf organic raw material revealed a significant variation from the experimental groups. This increasing count was more pronounced in the vermicompost produced from Eisenia foetida (Diospyros melanoxylon) tendu leaf litter compared with Eudrilus eugeniae worked Diospyros melanoxylon leaf litter produced vermicompost. The enhancement in fungal group from experimental vermicompost is attributed to the fungal diversity enhancement which reflects a different metabolic potentiality. This also indicates that the vermicompost produced from the organic raw material
E.eugeniae and E. foetida revealed an increase of $15.30 \%$ which was not significant.

which is having qualitative and quantitative fungal diversity could be used for field applications.

\section{Summary}

From our investigation it can be concluded that the vermicomposting of tendu leaf litter waste can be a viable method for converting the solid waste into useful manure. The vermicompost produced from beedi waste has rich microbial flora than the decomposed tendu leaf litter. E.foetida produced tendu leaf litter vermicompost has slightly enhanced fungal and phosphate solubilising fungi compared to E.euginae processed vermicompost.

\section{Future Scope}

The futuristic point of view, there are certain areas to be explored intensively to support the data base and also for agricultural applications.

1) Effect of processed tendu from beedi leaf litter on disease indices has to be high lightened.

2) To study the role of vermiwash produced from tendu leaf litter.

3) To study the importance of role of earthworm hormones in vermicompost

4) To educate people regarding proper disposal management practices and aftermath impacts to minimize the pollution.

\section{References}

[1] Aira, M., Monroy, F., Dominguez, J. and Mato, S. (2002) How earthworm density affects microbial biomass and activity in pig manure.European J. Soil Biol.38, 7-10.

[2] Alexei, T.V. and Stefan, S. (2000) Microfungal communities in soil, litter and casts of Lumbricus terrestris.Applied-Soil-Ecology14 (1):17-26.

[3] Anastasi, A., Varese, G.C. and Marchisio, V.F. (2005) Isolation and identification of fungal communities in compost and vermicompost. Mycologia 91(1):33-44.

[4] Booth, L.H., Hodge, S. and O'Halloran K. (2001) Use of biomarkers in earthworms to detect use and abuse of field applications of a model organophosphate pesticide. Bulln.Environ.Contam.Poll. 67:633-640.

[5] Cook, A and Luxton, M. (1980) Effect of microbes on food selection by Lumbricus terrestris.Rev.Ecol.Biol.Sol.17: 365-370.

[6] Daniel, O. and Anderson, J.M. (1992) Microbial biomass and activity in contrasting soil materials after passage through the gut of earthworms Lumbricus rubellus. (Hoffmeister) .Biol.Fertil.Soils.24:465-470.

[7] Daniel, T. and Karmegam, N. (1999) Bioconversion of selected leaf litters using African epigeic earthworms, Eudrilus eugenia. Ecol. Env.Cons, 5:271-275.

[8] Dubey, R.C. and Maheshwari, D.K. (1999) A Text Book of Microbiology, Chand \& Company Ltd, New Delhi pp.1-300 


\section{International Journal of Science and Research (IJSR) \\ ISSN (Online): 2319-7064 \\ Index Copernicus Value (2013): 6.14 | Impact Factor (2015): 6.391}

[9] Eastman.B.R. and Kane.P.N. Edwards.C.A., Trytek.L., Gunadi.B., Stermer.A.L. Mobley.J.R. (2001). The effectiveness of vermicolture in human pathogen reduction for USEPA biosolids stabilization. Compost Science \& Utilization. 9:38-49.

[10] Edwards, C.A. and Lofty J. R. (1977). Biology of Earthworms. Chapman and Hall John Wiley and Sons New York.

[11] Guerrero, R.D. (1983) The culture and use of Perionyx excavatus as a protein resources in the phillippines.In Satchell, J.E., ed. Eathworm ecology: from Darwin to vermiculture. Chapman and Hall, London, pp.309-313.

[12] Idowu, A.B., Edema, M.O and Adeyi, A.O. (2006) Distribution of bacteria and fungi in the earthworm Libyodrillus violaceous (Annelida: Oligochaeta), a native earthworm from Nigeria.Rev.Biol.Trop.54 (1):49-58.

[13] Ismail, S.A. (1997). Vermicology Biology of Earthworms. Orient Longman Ltd.pp.4-45.

[14] Kadam, D. G., Pathade, G.R., and Goel, P. K. (2005) Optimum concentration of supplementary feed for vermicomposting of tendu (Diospyros melanoxylon, Roxb.) Leaf refuses by Eudrilus eugeniae (Kinberg) Poll Res. 24: 259 - 262.

[15] Kale, R.D.(2000) An evaluation of the vermitechnology process for the treatment of agro, sugar and food processing wastes. Technology Appreciation Programme on Evaluation of Biotechnological approaches to waste Management held on 26th October 2000. Industrial Association-Ship of IIT, Madras, 1517.

[16] Khatavkar, R.S., Shah, N. V., Rao, K. R., Chavan, M. D., and Mushan, L. C. (2008) Vermicomposting of beedi (Indian Cigarette) leaf litter and its bioadsorbant utility. Eco. Env. and Cons. 14 (4): 613-616.

[17] Lynch, G.M. (1983) Soil biotechnology. Microbial factors in crop productivity. ELBS Blackwell Scientific Publication.

[18] Marlin Cynthia and Rajeshkumar. K.T, (2012). A study on sustainable utility of sugar mill effluent to vermicompost.Advances in Applied Science Research, 3(2):1092-1097.

[19] Mba, C.C. (1996) Treated-cassava peel vermicomposts enhanced earthworm activities and cowpea growth in field plots resources.Conser. recycling 17:219-226.

[20] Miller FC. 1996. Composting of Municipal Solid Waste and its Components. In: Palmisano AC, Barlaz MA, eds. Microbiology of Solid Waste. CRS Press. p 115154.

[21] Nagavallemma, K.P., Wani, S.P., Stephane Lacroix, Padmaja, V.V., Vineela, C., Babu Rao, M. and Sahrawat. K.L. (2004) Vermicomposting : Recycling wastes into valuable organic fertilizer. Global Theme on Agrecosystems Report no. 8. Patancheru 502 324, Andhra Pradesh, India: International Crops Research Institute for the Semi-Arid Tropics. pp.20.

[22] Nirmalnath, P.J., Biradar, A.P., Patil, M.B., Patil, A.B. (2006) Microflora associated with vermicompost obtained from different weeds.Kar. J. agricultural sciences.44-46.

[23] Parthsarathi, K. (2007) Influence of moisture on the activity of Perionyx excavates (Perrier and microbial - nutrient dynamics of pressmud vermicompost. Iran $\mathrm{J}$. Environ. Health Sci. Eng. 4. (3):147-156.

[24] Prasad.T.V.S (2011) A textbook of Soil Microbiology.Domoinant Publishers and Distributors. New Delhi. Reynolds, J.W. and Reynolds, W.M. (1972) Earthworms in Medicine. Am J Nurs, 72-1273.

[25] Saxena, H.N. (2006) Environmental studies .Rawat Publications.pp.8-30

[26] Solapur Action Plan - 2004 Maharashtra Pollution control Board. Revised action plan for control of air pollution in Solapur.

[27] Stratsma, G and Samson, R.A. (1993) Taxonomy of Scytodidium thermophilium, an important thermophilic fungus in mushroom compost. Mycol.Res.97: 321-328.

[28] Subba Rao, N.S. (2007) Soil microbiology (Fourth edition of soil microorganisms and plant growth) published by Oxford and IBH publishing Co.Pvt.Ltd.

[29] Summerbell RC. 1985. The staining of filamentous fungi with diazonium blue B. Mycologia 77:587-593.

[30] Suthar, S. (2006).Potential utilization of guargum industrial waste in vermicompost production Biores. technol. 97, 2474-2477.

\section{Author Profile}

Laxmi C. Mushan completed Ph.D from Shivaji University Kolhapur in 2010. 